\title{
Process-related key performance indicators for measuring sustainability performance of ecodesign implementation into product development
}

Rodrigues, Vinicius Picanco; Pigosso, Daniela Cristina Antelmi; McAloone, Tim C.

Published in:

Journal of Cleaner Production

Link to article, DOI:

10.1016/j.jclepro.2016.08.046

Publication date:

2016

Document Version

Peer reviewed version

Link back to DTU Orbit

Citation (APA):

Rodrigues, V. P., Pigosso, D. C. A., \& McAloone, T. C. (2016). Process-related key performance indicators for measuring sustainability performance of ecodesign implementation into product development. Journal of Cleaner Production, 139. https://doi.org/10.1016/j.jclepro.2016.08.046

\section{General rights}

Copyright and moral rights for the publications made accessible in the public portal are retained by the authors and/or other copyright owners and it is a condition of accessing publications that users recognise and abide by the legal requirements associated with these rights.

- Users may download and print one copy of any publication from the public portal for the purpose of private study or research.

- You may not further distribute the material or use it for any profit-making activity or commercial gain

- You may freely distribute the URL identifying the publication in the public portal 


\section{Accepted Manuscript}

Process-related key performance indicators for measuring sustainability performance of ecodesign implementation into product development

Vinícius P. Rodrigues, Daniela C.A. Pigosso, Tim C. McAloone

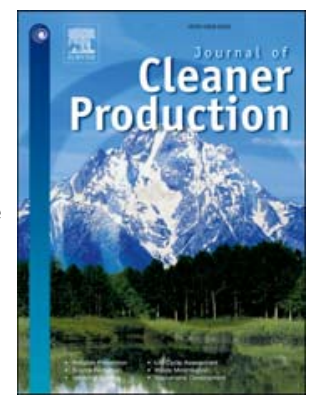

PII:

S0959-6526(16)31190-8

DOI:

10.1016/j.jclepro.2016.08.046

Reference: JCLP 7838

To appear in: Journal of Cleaner Production

Received Date: 26 January 2016

Revised Date: 4 July 2016

Accepted Date: 9 August 2016

Please cite this article as: Rodrigues VP, Pigosso DCA, McAloone TC, Process-related key performance indicators for measuring sustainability performance of ecodesign implementation into product development, Journal of Cleaner Production (2016), doi: 10.1016/j.jclepro.2016.08.046.

This is a PDF file of an unedited manuscript that has been accepted for publication. As a service to our customers we are providing this early version of the manuscript. The manuscript will undergo copyediting, typesetting, and review of the resulting proof before it is published in its final form. Please note that during the production process errors may be discovered which could affect the content, and all legal disclaimers that apply to the journal pertain. 


\title{
Process-related key performance indicators for measuring sustainability performance of ecodesign implementation into product development
}

\author{
Vinícius P. Rodrigues ${ }^{*}$, Daniela C. A. Pigosso, Tim C. McAloone \\ Technical University of Denmark, Department of Mechanical Engineering, Building 426, Produktionstorvet, \\ 2800 Kgs. Lygnby, Denmark \\ * Corresponding author (+45 523991 10) \\ E-mail addresses: vipiro@dtu.dk(Vinicius P.Rodrigues),danpi@mek.dtu.dk(Daniela C.A.Pigosso), \\ tmca@dtu.dk(Tim C.McAloone)
}

\section{Introduction}

Sustainability measurement aims to support decision-makers in the evaluation of its performance while providing substantial information for planning future actions (Mccool and Stankey, 2004). There is a clear consensus that the development of concrete tools for promoting and measuring achievements in sustainability should be pursued (Veleva and Ellenbecker, 2001). In that respect, sustainability indicators are widely accepted for measuring performance and achievements in different levels within the organization and outside of it (Keeble et al., 2003; Veleva et al., 2003).

Companies, in particular, must play a prominent role in achieving sustainable development and demonstrating steady improvement of its triple bottom-line performance (Azapagic, 2003; Elkington, 1997). The adoption of sustainability initiatives is seen as a source of competitive advantage, providing companies with more mechanisms for improving risk management and driving relevant changes in internal aspects, such as culture and structure (Azapagic, 2003; Hynds et al., 2014; Short et al., 2012; Willard, 2005). In a broader context, Willard (2005) lays the foundation and assumptions of a business case ${ }^{1}$ for the integration of sustainability practices into corporate strategies (Short et al., 2012), which can be constantly enhanced and achieved by a proper measurement of sustainability performance progress. Therefore, the activity of measuring sustainability is crucial for embedding the subject into the company's decision-making process and management systems (Delai and Takahashi, 2011).

For manufacturing companies specifically, the development of products with improved environmental performance is increasingly part of their engagement towards sustainable development (Bevilacqua et al., 2007; Gaziulusoy et al., 2013; Hallstedt et al., 2013). Therefore, ecodesign emerges as a proactive approach for integrating environmental aspects into product development and related processes, such as manufacturing, marketing, procurement etc. (Pigosso et al., 2013, 2015). The underlying assumption is that the integration of ecodesign practices into business processes leads to products with better environmental performance (Pigosso et al., 2013), defined as the sum of all environmental impacts across a product's material lifecycle (Nielsen and Wenzel, 2002).

Ecodesign presents a set of potential business benefits, such as increased innovation potential, development of new markets and business models, reduction in environmental liability, risks and costs, improvement of organizational brand and legal compliance, among others (Bevilacqua et al., 2007; ISO, 2011, 2002; Pigosso et al., 2013; Plouffe et al., 2011; Van Hemel and Cramer, 2002). However, there are several challenges that still hinder the adoption of ecodesign by companies (Boks and Stevels, 2007; Boks, 2006; Fiksel et al., 1998), mainly related to capturing and measuring the projected business benefits of ecodesign. These challenges can be divided into two dimensions (Pascual and Stevels, 2004; Pigosso and Rozenfeld, 2012; Pigosso et al., 2013): (i) managerial dimension, encompassing business aspects and alignment with related processes and (ii) operational dimension, related to the technicalities of the product, such as physical characteristics, materials, energy etc.

In order to overcome many of these challenges and build a compelling collection of arguments and rationales to support ecodesign implementation, a business-oriented and managerial approach should be delineated and targeted at top-level management (Pigosso et al., 2013). However, since there has been a primary focus on evaluating ecodesign in terms of environmental performance and product-related (technical) measures

\footnotetext{
${ }^{1}$ A business case can be defined as the set of arguments or rationales that supports and documents the reasons why the business community should accept or advance a certain cause (Carroll and Shabana, 2010).
} 
(Handfield et al., 2001), the use of key performance indicators (KPI) to measure ecodesign from process-related perspective is not fully explored. Furthermore, the reported benefits of ecodesign go beyond the pure environmental dimension and span across the social and economic dimensions (Ambec and Lanoie, 2008; EDC, 2014; Mathieux et al., 2001; Plouffe et al., 2011), requiring an approach based on the triple bottom line to address and further quantify the potential benefits of integrating ecodesign into product development. This approach enables companies to address ecodesign implementation from a more holistic and integrated perspective, harmonizing the economic and non-economic benefits and covering aspects such as regulation compliance, competitiveness, stakeholder satisfaction, among others (Haned et al., 2015).

There are circumstances in which companies develop a combination of products and services in the so-called product/service-systems (PSS). The transition towards PSS has been raising interest and a specific investigation over sustainability indicators as a means for supporting companies to evaluate the application feasibility of sustainable PSS-based models is proposed by Sundin et al. (2015), with a focus on environmental issues. Even though the results of this paper can be extended, adapted and translated accordingly, this research focus is primarily positioned upon the development of physical products - therefore, the specificities of this transition fall outside the scope of the paper.

Within this context, the goal of this paper is to identify a comprehensive set of sustainability KPIs for product development processes, aimed at answering the question "which are the process-related KPIs for measuring sustainability performance of product development processes?". Therefore, the major difficulties and challenges that are addressed in this paper are related to: (i) the limited focus on managerial perspective in ecodesign performance measurement; (ii) the lack of approaches that tackle ecodesign beyond the technical and environmental facets and (iii) the lack of a systematized outlook on process-related indicators for product development from an organizational perspective. Furthermore, it is noteworthy that it is an exploratory research in its nature, which is geared towards gathering relevant performance indicators and setting the theoretical foundation for building future practical applications. The specific application of the indicators in practical context is not within the scope of this paper, and will be explored in future research. In the following section, the research methodology employed in this research is presented in detail. Section 3 describes the main results obtained by the systematic literature review, followed by discussions (Section 4) and final considerations and remarks (Section 5).

\section{Research Methodology}

The overall research approach was formed by two phases, divided into 5 steps. The first phase consisted of a three-step systematic literature review to gather the available KPIs in the literature. The second phase of the review comprised two steps, encompassing KPI systematization, along with a critical analysis based on comparisons with other KPI studies in product development, specifically in the context of ecodesign (Issa et al., 2015; Pigosso and Rozenfeld, 2012; Pigosso et al., 2013). The overall research approach is shown in Figure 1. The systematic literature review followed the procedure proposed by Biolchini et al., 2005, based on the following steps: (1) review planning; (2) review execution and (3) results analysis.

In the first step (planning), a literature review protocol was prepared based on the research objective and a set of defined inclusion criteria. The second step, encompassing the execution of the literature search procedures, identified the primary studies, which were then selected and evaluated according to the inclusion criteria that were defined and established in protocol. As the studies had been selected, relevant data from the paper were captured, extracted and analyzed during the last step (Biolchini et al., 2005). 


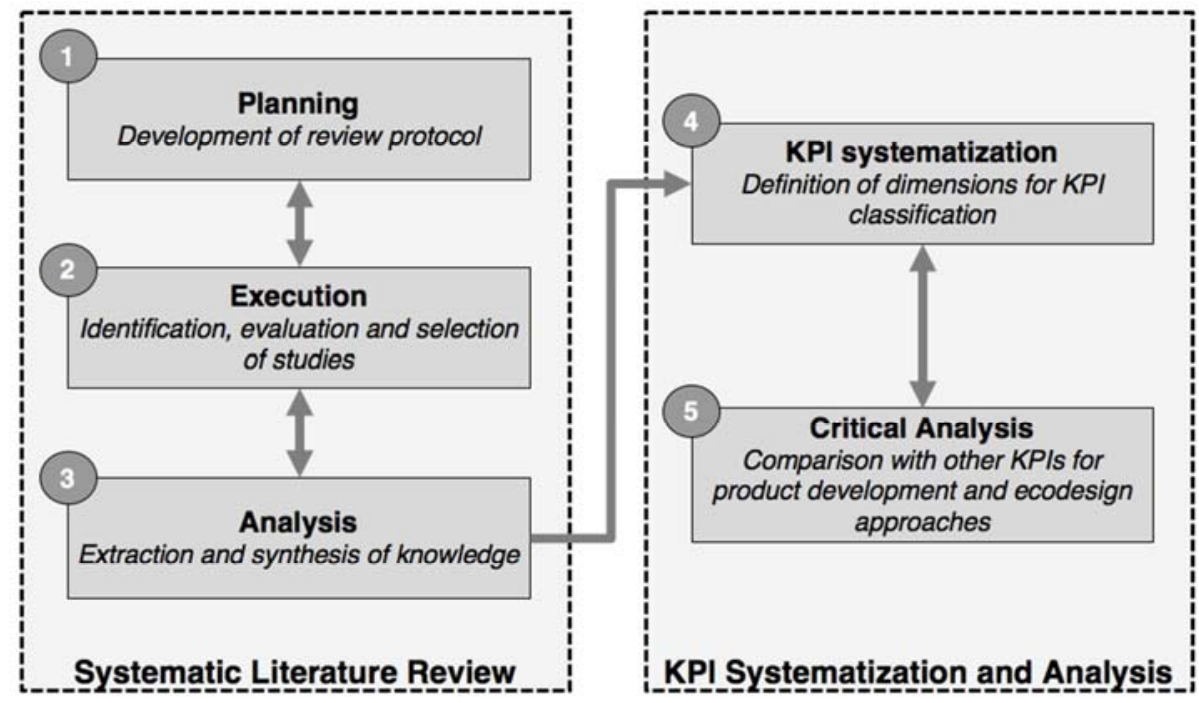

Figure 1 - The overall research approach with two phases divided into 5 steps

The main objective of the systematic literature review was to identify the available process-related KPIs to be applied in product development processes. Consequently, the selected search keywords are related with KPIs and product development, and their synonyms. The terms metric, measure, measurement and indicators are often used interchangeably (Costa et al., 2014) and, therefore, in this paper, we use the term "key performance indicators" or only "indicators" as a generic term and a synonym encompassing metric, measure and other terms (for a broader discussion see, for example, Keong Choong (2013)). Additionally, in order to obtain more relevant results, the keywords for KPIs were searched on the titles of the papers, whereas the keywords for product development were searched on the topic, usually covering the paper's title, abstract and keywords. An exception to this rule was made with the term "performance measurement system", which was inserted in the topic field, provided it is a more generic term to refer to a set of performance indicators and their relationships with the environment they operate (Neely et al., 2005). Therefore, after a set of refinement rounds, the string was composed of the term "key performance indicator" and 6 synonyms ("metric", "index", "indices", "measure", "indicator" and "threshold"), and "product development" and 3 synonyms ("product design", "engineering design" and "concurrent engineering").

Two indexed electronic databases were used in this research, ISI Web of Knowledge and Scopus, due to availability of advanced web search mechanisms, high volume of indexed papers and proven relevance in the fields of research (see, for example, Adriaanse and Rensleigh, 2013; Gavel and Iselid, 2008). The searches included both journal and peer-reviewed conference papers, in order to guarantee comprehensiveness and capture the recent researches under development in different fields. The research fields were limited to cover business, economics, engineering, information and library sciences, environmental sciences, ecology, sociology, operations research/management science and social issues. In order to guarantee the comprehensiveness of the literature review, there were made no restrictions regarding the publication dates in the databases systems. Adaptions and adjustments to the search string and the terminology of the research fields were made according to each database's rules of operation for search queries.

For the evaluation and selection of the relevant papers, two inclusion criteria were defined. The paper must: (1) contain, at least, one KPI for product development and (2) focus on the product development process rather than the product itself. Therefore, indicators dealing directly and exclusively with product's attributes and properties, such as energy, material consumption etc., were excluded. With these criteria, the review intended to cover the studies that were originally proposing new KPIs as well as those that were reporting, analyzing, re-defining or simply presenting indicators as a result of their own literature review. Based on these criteria, the procedure for study analysis and selection was based on three steps: (a) read the title, (b) read the abstract and keywords, (c) read the introduction and conclusion and (d) read the full paper.

The second phase of the research involved the systematization of the retrieved KPIs. Once the KPIs were identified, they were subsequently documented according to the following attributes: name, description and/or formula and bibliographic information (authors and year of publication). After documentation, they were classified according to:

- Triple bottom line dimensions (Elkington, 1997): economic, social, environmental, or any combination of the three dimensions - this classification was selected due to its high dissemination and usage both 
in the academic and corporate domains, and the fact that the reported benefits of ecodesign in the literature are made in terms of triple bottom line dimensions. Therefore, this classification will enable a more direct and straightforward connection with the potential ecodesign benefits;

- $\quad$ phases of product development process: Product Strategic Planning, Informational Design, Conceptual Design, Detailed Design, Production Preparation, Product Launch, Product Accompanying and Monitoring and Generic Activities. These phases were adapted from the reference model for product development suggested by Amaral and Rozenfeld (2007) and Rozenfeld (2007). This classification can be easily translated into different reference models for product development processes;

- unit of measurement, as a way to support and complement the definition of each one of the KPIs, which can take the form of financial or non-financial instances and be expressed in terms of metric or a measure (Keong Choong, 2013).

Another possible categorization for the performance indicators could be achieved by classifying them in either leading or lagging indicators - the former shows trends and inspire alternative courses of action for improving performance, while the latter consolidates the results (outputs) of an action. This type of classification and subsequent discussions were not utilized in the context of this research because it falls outside the scope of this paper. However, this alternative classification can be performed in future research.

Generally, sustainability evaluations are made on the grounds of the triple bottom line dimensions - economic, social and environmental - as a way to measure corporate sustainability performance by adding two new and constantly overlooked dimensions on top of the traditional economic and financial indicators (Gauthier, 2005; Hutchins and Sutherland, 2008). When the economic, social or environmental dimensions are considered separately, they lead to one-dimensional indicators, while the combinations of two dimensions produce bidimensional indicators, such as the socio-economic, socio-environmental or eco-efficiency indicators (Labuschagne et al., 2005; Sikdar, 2003). Therefore, in order to classify the KPIs in theses dimensions, a clearcut description of the three types of sustainability indicators was needed. Based on the definitions and discussions on sustainability dimensions in corporate strategies (Baumgartner and Ebner, 2010) and reference models for sustainability measurement and indicators (Delai and Takahashi, 2011; Keeble et al., 2003; Labuschagne et al., 2005; Mccool and Stankey, 2004; Meadows, 1998; United Nations Global Compact, 2014), we describe them as follows:

- Economic dimension: it is usually regarded as a 'generic dimension' (Baumgartner and Ebner, 2010) that captures an organization's aspects that have to be addressed in order to remain competitive in the market on the long-run. It also encompasses a set of measures to assess the value creation by a company and its stakeholders, both in the short and long terms (Delai and Takahashi, 2011) and it should be tackled at the local, national and global levels (GRI, 2014);. This sustainability dimension includes several components, such as:

- profit and value (assessed by traditional financial measures);

investments (capital employed and Research and Development - R\&D);

relationship with investors (corporate governance and shareholder's remunerations);

crisis management (Delai and Takahashi, 2011);

innovation and technology, collaboration, knowledge management, processes, purchase and sustainability reporting (Baumgartner and Ebner, 2010).

- Social dimension: while argued as a neglected dimensions and a 'concept in chaos'(Vallance et al., 2011), it can be defined as the dimension that is related to an organization's impacts on the social system in which it operates (GRI, 2014), dealing with human wellbeing, the fulfillment of human needs and the equal development of opportunities for all people (United Nations, 2007). The social sustainability aspect is aimed at influencing the relationships with stakeholders in a positive way, both the current as well as the future ones. Stakeholders are defined as groups affected by the organization, such as employees, customers, suppliers, legal and governmental entities and society at large (Baumgartner and Ebner, 2010; Bourne et al., 2002; Delai and Takahashi, 2011; Neely et al., 2002). The aspects of this dimension can be categorized in internal aspects, such as motivation and incentives, health and safety and human capital development, and external aspects, such as ethical behavior and human rights, no controversial activities, no corruption and cartel and corporate citizenship (Baumgartner and Ebner, 2010). Additionally, Delai and Takahashi (2011) propose, based on extensive research and analysis of eight different sustainability measurement initiatives, the following aspects for social dimension:

- labor practices and decent work (such as employee's education, training and development, diversity and opportunity, health and safety, job creation, talent attraction and retention and human rights); 
- customer relationship management (customer satisfaction, customer health and safety, products and labels, advertising and respect for customer privacy);

- corporate citizenship (social actions, political contributions, codes of conduct, corruption \& bribery, competition and pricing and society communication);

- suppliers and partners (contracts and selection, evaluation and development of suppliers) and

- public sector (subsidies and taxes).

- Environmental dimension: this dimensions deals with the ecosystem wellbeing (Delai and Takahashi, 2011) and the environmental impacts, for which organization contribute by reducing resources consumption, waste generation and negative impacts on the use of land, water and air (GRI, 2014). Therefore, it may encompass the following aspects, for instance (Baumgartner and Ebner, 2010; Bhander et al., 2003; Delai and Takahashi, 2011; McAloone and Bey, 2009; Nielsen and Wenzel, 2002; Seuring and Müller, 2008; United Nations, 2007):

emissions to air (atmospheric acidification, photochemical ozone formation etc.); emissions into the ground (usage and waste generation); materials (consumption and use of hazardous materials); energy consumption;

water (consumption, acidification, aquatic oxygen demand, ecotoxicity to aquatic life and eutrophication);

- biodiversity (ecosystems, protected areas and species) and environmental issues of products and services over the whole life cycle.

\section{Results}

The review resulted in 1.179 papers retrieved: 711 from Scopus, 270 from ISI Web of Science and 198 papers indexed in both databases. By applying the inclusion criteria and following the procedure for study analysis and selection, 762 papers $(64.6 \%$ of total) had their abstract and keywords analyzed, whereas introduction and conclusion were analyzed in 327 papers ( $42.9 \%$ of previously selected papers) and 45 papers were fully read and finally selected, representing $13.7 \%$ of the previously selected papers. From the total number of retrieved papers, the 45 selected ones represent a yield of $3.8 \%$. Figure 2 depicts a summary of the results from papers' analysis and selection.

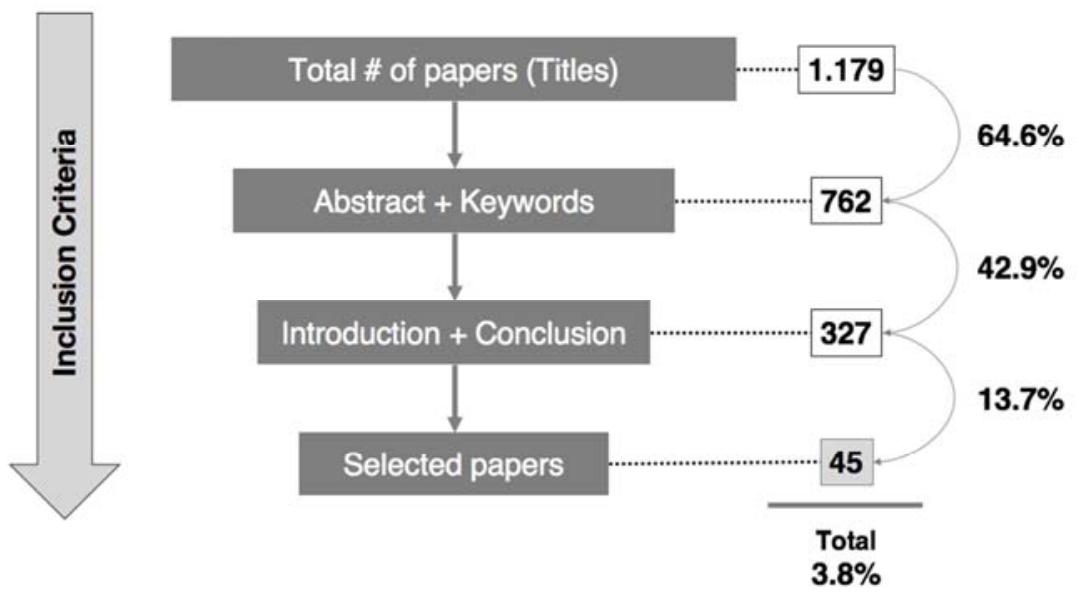

Figure 2 - Application of the inclusion criteria

The selected papers were published in a total of 21 different journals and 12 scientific conferences, with 19 different publication years, spanning from 1993 to 2015. Figure 3 shows the distribution of selected papers in terms of the publication years for journals and conferences. 


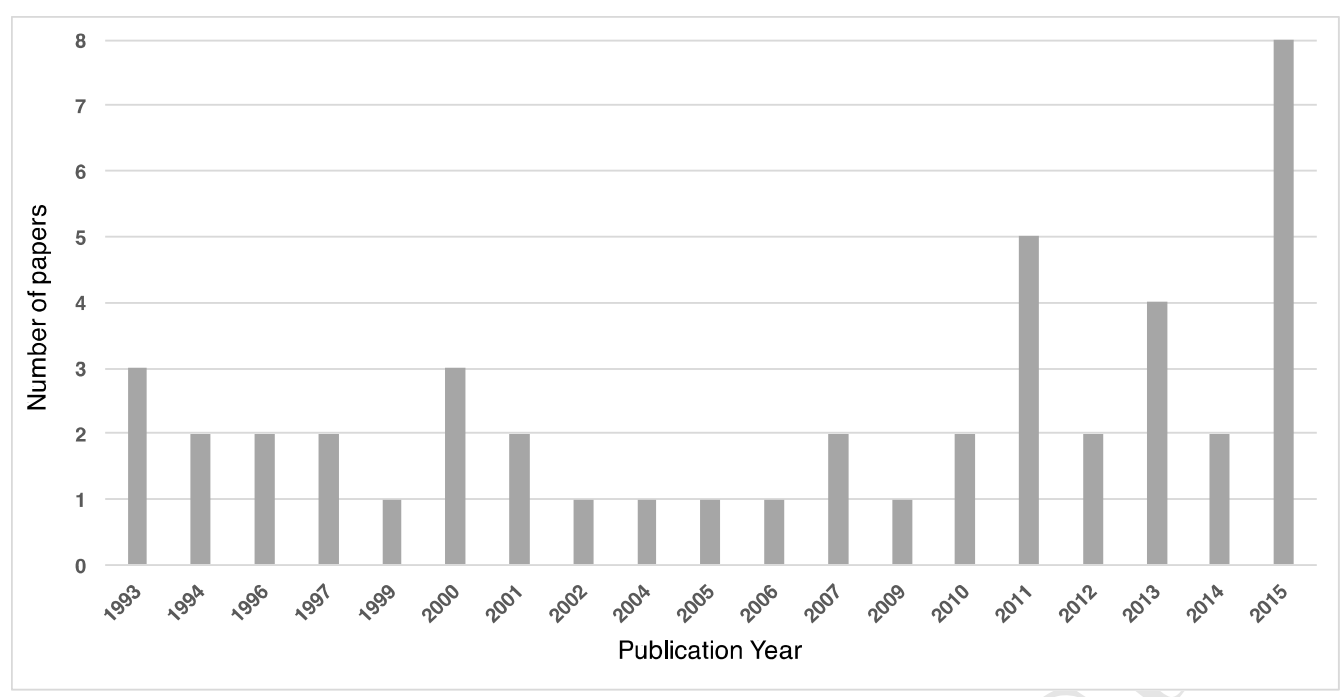

Figure 3 - Distribution of selected papers by publication year for journals and conferences

The selected publications presented, to a certain extent, a uniform distribution in the 1990's and early 2000's, followed by an alternating increase in the coming years, with 5 selected papers in 2011, 4 papers in 2013 and an absolute peak in 2015, with 8 papers. Only two KPI review-based papers were identified in the systematic literature review: a literature review, followed by a survey-based evaluation of lean metrics in the context of program management for Research and Development (R\&D) (Costa et al., 2014) and the study of the incorporation of sustainability indicators into performance measurement systems from a Product Lifecycle Management perspective, which is described in the work of (Nappi and Rozenfeld, 2015).

Since this research is exploratory in its nature, with a focus of gathering available process-related KPIs from multiple sources in the literature, we highlight the distribution among the different journals and conferences that published relevant works. This is a proxy for the main research and knowledge areas that are contributing to the definition and proposal of process-related KPI. This is particularly relevant for future studies that will build on top of the systematized KPIs, as a mechanism of sorting out the fields to focus on or from where to retrieve relevant information.

Out of the 45 selected papers, 32 of them were retrieved from academic journals. Figure 4 shows the distribution of papers by journals.

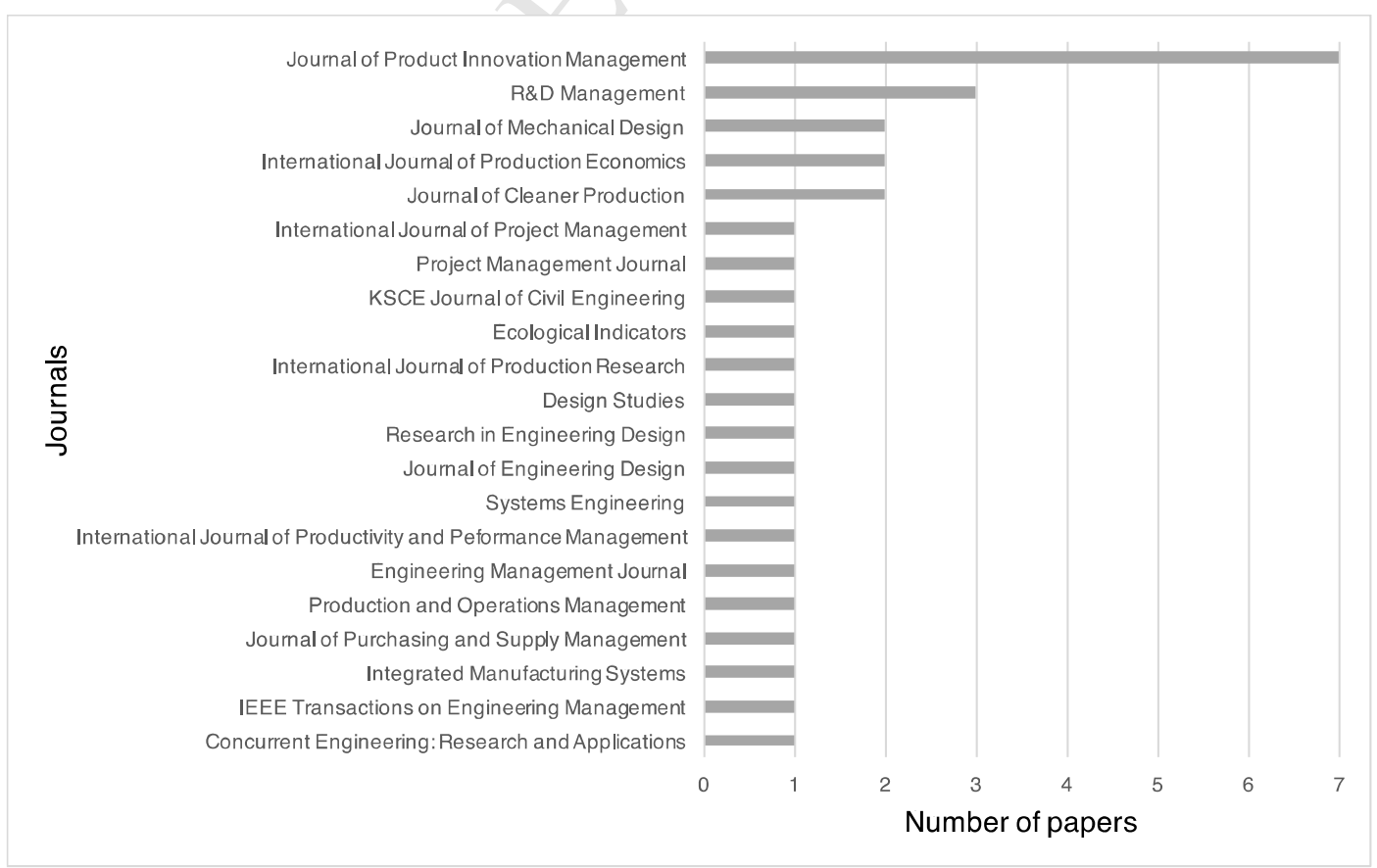

Figure 4 - Distribution of selected papers by journal 
It is worth noting that the representations from sustainability-related literature are made by 3 publications only: two papers from the Journal of Cleaner Production and one paper from Ecological Indicators. This might indicate that this research area has not been focusing on product development from a process perspective when it comes to discussing and measuring sustainability.

The other 13 selected papers were retrieved from conference proceedings. Figure 5 shows the distribution of papers by conferences. With the International Conference on Engineering Design (ICED) being the only exception with 2 selected papers, the other 11 conferences provided one paper each.

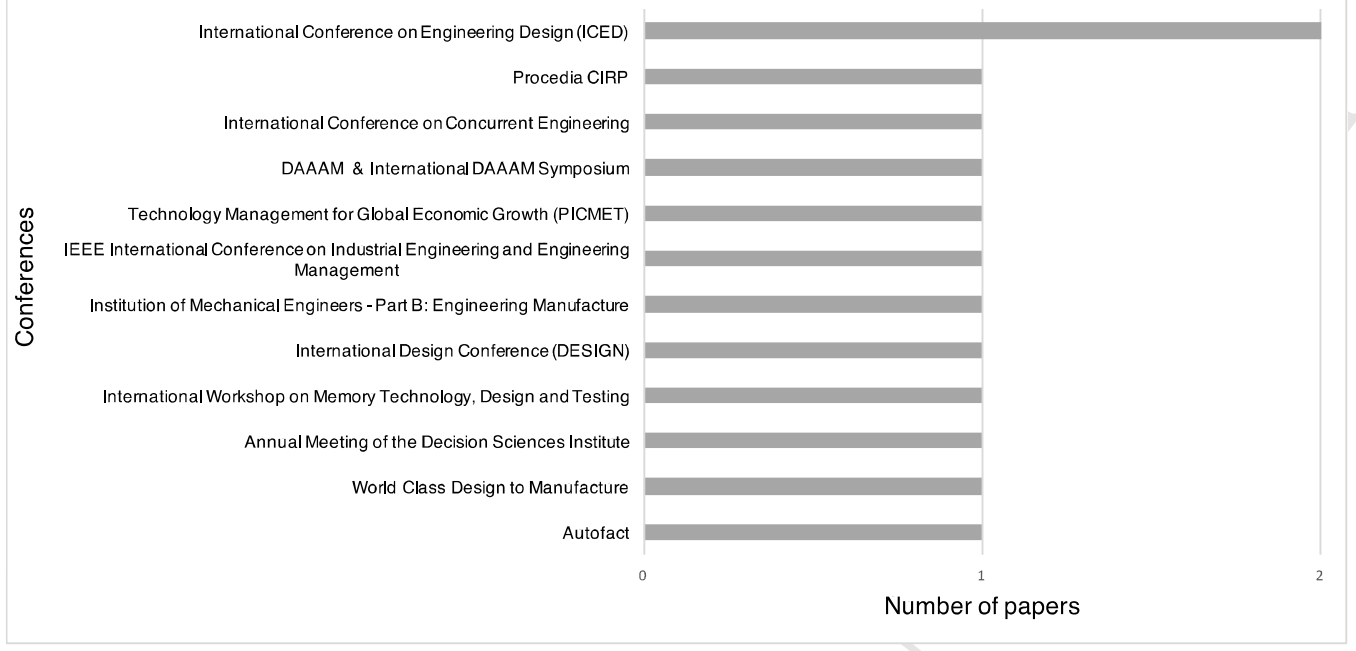

Figure 5 - Distribution of selected papers by conference

The conferences cover more technical aspects in the areas of design, engineering and management, when compared to the scope of the presented journals. It is also worth noting that there is lack of conferences focused on sustainability-related themes.

From the 45 papers, approximately 830 process-related indicators for product development processes that met the defined inclusion criteria were initially identified and catalogued. The duplicates were removed and the indicators were consolidated in a single standard spreadsheet with a final total of 787 systematized KPIs, representing an average of $17.4 \mathrm{KPIs}$ per selected paper. After consolidation, the KPIs had their name, description and/or formula and bibliographic information (authors and year of publication) documented.

Subsequently, they were classified according to the triple bottom line dimensions and the phases of product development process as shown and discussed in Section 2. The distribution of KPIs according to the triple bottom line dimensions is shown in Figure 6. Approximately $74.2 \%$ of the KPIs (584 out of 787) were classified as economic indicators, such as 'man-hour spending' (Chang and Tsai, 2015), whereas social indicators, like 'skills comparison (real vs. required)' (Durkacova et al., 2012), accounted for 19.2\% (151 out of 787) and environmental indicators, as in 'degree to which the product meets environmental legislation requirements' (Ussui and Borsato, 2013), totalized 3.2\% (25 out of 787). In the past few years, there was an extensive and dominant development of economic indicators for measuring corporate performance. Although they might not, per se, point towards the very essence and precepts of a sustainability-based reasoning as such, they were included in this research since the economic aspect constitutes one of the dimensions of the triple bottom line formulation.

The tri-dimensional indicators, touching upon all three dimensions of sustainability at the same time, such as 'number of sustainability aspects (social, environmental and economic) considered in the project scope' (Ussui and Borsato, 2013), represented 2.0\% (16 out of 787) of the total. The bi-dimensional indicators of economic and social dimensions, as in 'monetary value of minority purchases' (Nappi and Rozenfeld, 2015, 2013) accounted for $0.9 \%$ (7 out of 787), while 2 indicators covered social and environmental dimensions simultaneously, with 'number of employees with incentives linked to environmental goals'(Nappi and Rozenfeld, 2015, 2013) as an example, representing $0.2 \%$ ( 2 out of 787). Lastly, only 2 indicators referred to the economic and environmental dimensions accounted for $0.2 \%$ of the total registered KPIs, namely 'monetary value of significant fines and total number of non-monetary sanctions for noncompliance with environmental laws and regulations', which was retrieved by the works of (Nappi and Rozenfeld, 2015, 2013) and originally proposed in the Global Reporting Initiative (GRI) (GRI, 2014). 


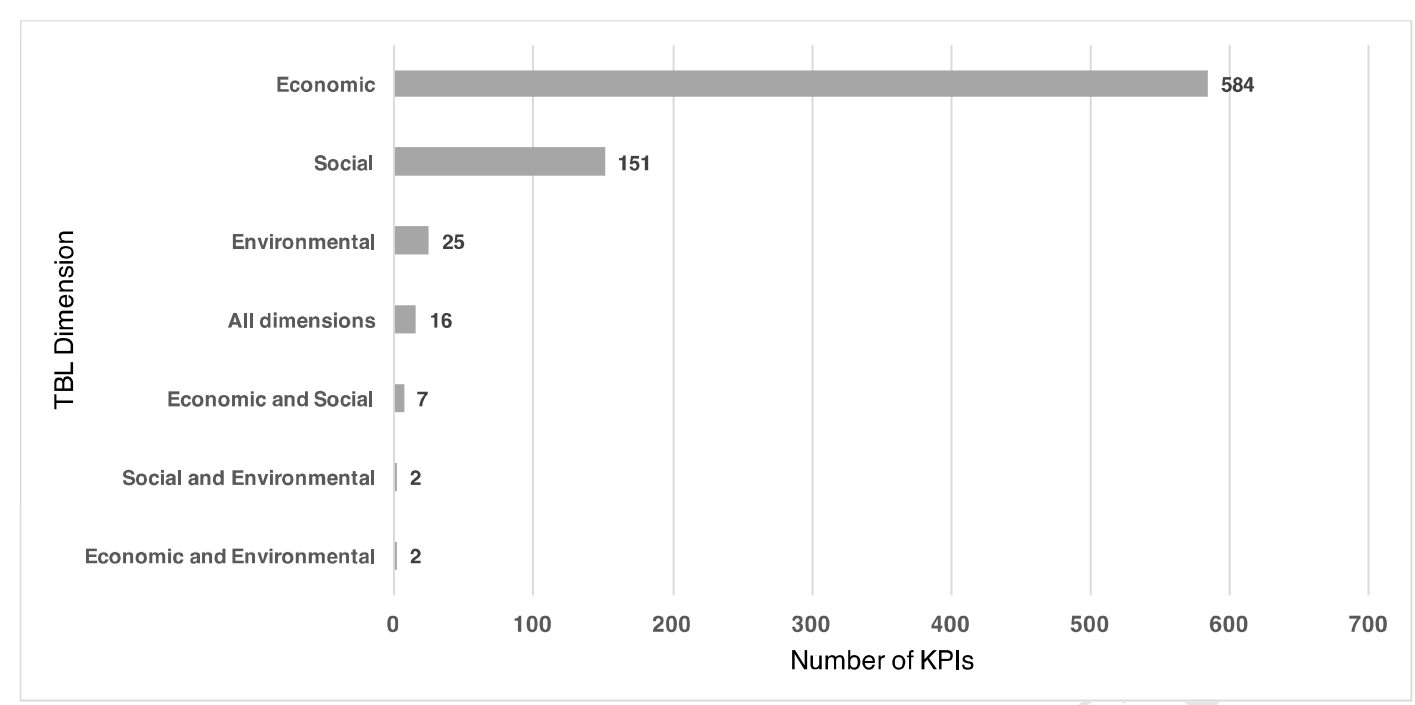

Figure 6 - Distribution of KPIs by triple bottom line dimension

In terms of the distribution of the KPIs across the whole product development process, from Product Strategic Planning to Product Accompanying and Monitoring, Figure 7 depicts the number of KPIs for each one of phases of the process. Many KPIs cover more than one single phase, meaning it is suitable to be applied at different times along the process, depending on the specific focus, the company's circumstances and how their actual product development process is structured and defined. The single phase with most specific KPIs is the Product Strategic Planning phase, with 114 indicators, representing $14.5 \%$ of the total KPIs. It is followed by Product Accompanying and Monitoring with 49 indicators (6.2\%), Production Preparation (1.3\%), Conceptual Design (0.9\%), Product Launch (0.6\%), Detailed Design $(0.4 \%)$ and Informational Design $(0.3 \%)$. However, the majority of the KPIs, representing $60.7 \%$ of all the gathered indicators, is defined in terms of Generic Activities, which can be applied and used throughout the whole process. The remaining indicators are classified as a combination of 2,3 , or 4 different phases of the product development process. 
Phases of Product Development

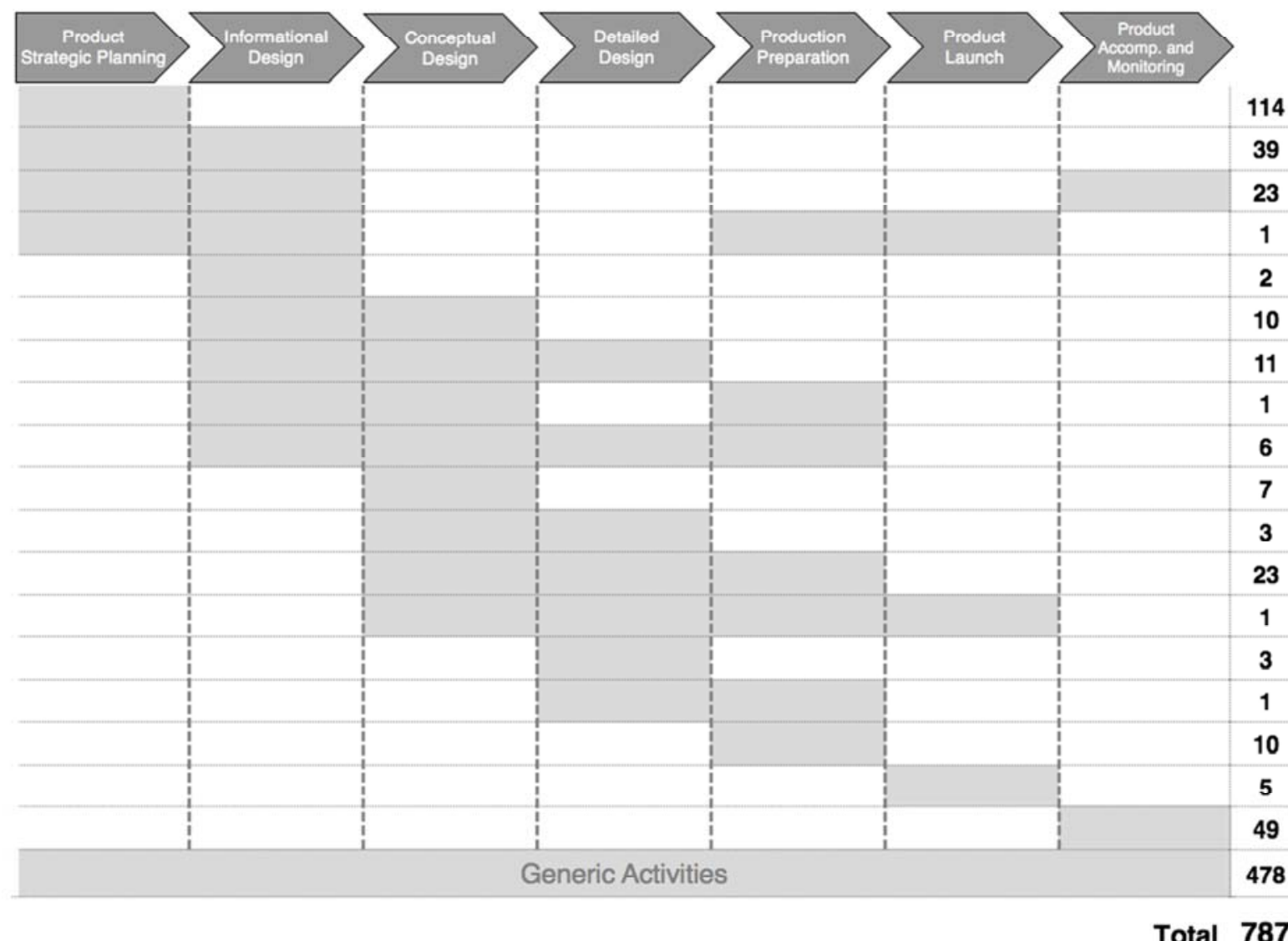

Figure 7 - Distribution of KPIs across the phases of the product development process (Process reference model adapted from Amaral and Rozenfeld (2007) and Rozenfeld (2007))

Table 1 presents examples of KPIs, classified according to the phases of product development, as well as the respective triple bottom line dimension. The complete spreadsheet of KPIs is available for download through the website address: http://www.ecodesign.dtu.dk/process-performance.

Table 1 - Examples KPI for each product development phase and its combinations

\begin{tabular}{|c|c|c|c|c|c|c|c|c|c|}
\hline \multirow[b]{2}{*}{ Key Performance Indicator } & \multirow{2}{*}{\begin{tabular}{c}
\multicolumn{1}{c}{ Triple } \\
Bottom Line \\
Dimension \\
\end{tabular}} & \multicolumn{7}{|c|}{ Product Development Phases* } & \multirow{2}{*}{ Reference } \\
\hline & & PSP & IDE & CDE & DDE & PPR & PLA & PAM & \\
\hline External acquisition of $\mathrm{R} \& \mathrm{D}$ & Economic & & & & & & & & (Luz et al., 2015) \\
\hline $\begin{array}{l}\text { Considerations of sustainability } \\
\text { aspects in the project scope }\end{array}$ & $\begin{array}{c}\text { Social, } \\
\text { Environmental } \\
\text { and Economic }\end{array}$ & & & & & & & & $\begin{array}{l}\text { (Ussui and } \\
\text { Borsato, 2013) }\end{array}$ \\
\hline $\begin{array}{l}\text { Degree to which the product meets } \\
\text { environmental legislation } \\
\text { requirements }\end{array}$ & Environmental & & & & & & & & $\begin{array}{l}\text { (Ussui and } \\
\text { Borsato, 2013) }\end{array}$ \\
\hline $\begin{array}{l}\text { Purchase intent rate prior to market } \\
\text { introduction }\end{array}$ & Economic & & & & & & & & $\begin{array}{c}\text { (Griffin and Page, } \\
\text { 1993) }\end{array}$ \\
\hline $\begin{array}{l}\text { Considerations for improving } \\
\text { sustainability at the end-of-life }\end{array}$ & $\begin{array}{c}\text { Social, } \\
\text { Environmental } \\
\text { and Economic }\end{array}$ & & & & & & & & $\begin{array}{l}\text { (Ussui and } \\
\text { Borsato, 2013) }\end{array}$ \\
\hline $\begin{array}{c}\text { Requirements stability and } \\
\text { volatility }\end{array}$ & Economic & & & & & & & & $\begin{array}{c}\text { (Vanek et al., } \\
2008) \\
\end{array}$ \\
\hline Expected reuse for products & Economic & & & & & & & & (Hauser, 2001) \\
\hline $\begin{array}{l}\text { Lead time from agreement of } \\
\text { requirements to manufacture }\end{array}$ & Economic & & & & & & & & $\begin{array}{l}\text { (Haque and } \\
\text { Moore, 2004) }\end{array}$ \\
\hline
\end{tabular}




\begin{tabular}{|c|c|c|c|}
\hline $\begin{array}{l}\begin{array}{l}\text { Number of engineer changing } \\
\text { orders }\end{array} \\
\end{array}$ & Economic & & $\begin{array}{c}\text { (Acosta et al., } \\
2002)\end{array}$ \\
\hline Concept's variety & Economic & & $\begin{array}{c}\text { (Oman et al., } \\
\text { 2013; Shah et al., } \\
2000)\end{array}$ \\
\hline $\begin{array}{l}\text { Improvement potential of selected } \\
\text { concepts }\end{array}$ & Economic & & $\begin{array}{c}\text { (Ussui and } \\
\text { Borsato, 2013) }\end{array}$ \\
\hline Drawings 'first-time pass' & Economic & & (Buchheim, 2000) \\
\hline $\begin{array}{l}\text { Number of design defects detected } \\
\text { at development stages }\end{array}$ & Economic & & $\begin{array}{c}\text { (Nappi and } \\
\text { Rozenfeld, 2015) }\end{array}$ \\
\hline $\begin{array}{c}\text { Economic feasibility in detailed } \\
\text { design }\end{array}$ & Economic & & $\begin{array}{c}\text { (Ussui and } \\
\text { Borsato, 2013) } \\
\end{array}$ \\
\hline $\begin{array}{l}\text { Planned versus actual formal test } \\
\text { procedures attempted/completed }\end{array}$ & Economic & & $\begin{array}{c}\text { (Vanek et al., } \\
\text { 2008) }\end{array}$ \\
\hline $\begin{array}{l}\text { Product yield rate through the } \\
\text { manufacturing process }\end{array}$ & Economic & & $\begin{array}{c}\text { (Griffin and Page, } \\
1993)\end{array}$ \\
\hline Launched on time and in budget & Economic & & $\begin{array}{c}\text { (Griffin and Page, } \\
1996,1993)\end{array}$ \\
\hline Change in customer loyalty & Social & & (Bai et al., 2007) \\
\hline Environmental budget & $\begin{array}{l}\begin{array}{l}\text { Environmental } \\
\text { and Economic }\end{array} \\
\end{array}$ & \multirow{4}{*}{ Generic Activity } & (Garbie, 2014) \\
\hline Attracted foreign researcher & Social & & $\begin{array}{c}\text { (Kim and Kim, } \\
2015)\end{array}$ \\
\hline Number of products with eco-label & Environmental & & $\begin{array}{c}\text { (Nappi and } \\
\text { Rozenfeld, 2015) } \\
\end{array}$ \\
\hline $\begin{array}{c}\text { Environmental information } \\
\text { availability and accuracy }\end{array}$ & Environmental & & $\begin{array}{c}\text { (Nappi and } \\
\text { Rozenfeld, 2015) }\end{array}$ \\
\hline
\end{tabular}

* PSP: Product Strategic Planning; IDE: Informational Design; CDE: Conceptual Design; DDE: Detailed Design; PPR: Production Preparation; PLA: Product Launch; PAM: Product Accompanying and Monitoring

Approximately $90 \%$ of the KPIs presented in the selected studies were not accompanied by explicit units of measurement. However, in order to support the definition and classification of the KPIs as well as provide a sense of direction and magnitude, a set of 112 different units of measurement were assigned to the KPIs, based on their name and other additional information eventually presented on the specific study. Approximately $55 \%$ of the KPIs has their unit of measurement solely classified as 'dimensionless', which means they are either to be expressed in relative (percentage) measures, such as 'percentage of design changes occurring after design data release to manufacture' (Haque and Moore, 2004) or requires the development, application or adaption of a scale-based measure, such as 'professional esteem' (Drongelen and Bilderbeek, 1999) and 'supplier satisfaction index' (Humphreys et al., 2007). Some examples of the assigned units include: unit of time, monetary units, number of tasks, number of requests, number of stakeholders, meetings per unit of time, monetary units per unit of time, man-hours, number of alliances, number of adaptations, number of lawsuits, number of agreements, number of certifications, number of cancellations, number of reviews, number of customers, units of data, number of patents, number of uses per unit of time, among others.

The 19 publication years of the selected papers can be divided into 4 intervals, which are roughly homogeneous in terms of the number of years in each interval: 1993-1999, 2000-2005, 2006-2010 and 2011-2015. These time intervals were selected with a view to representing the evolution perspectives across different triple bottom line dimensions along the years and tracking the number of proposed KPIs. Although the KPIs proposed from 1993 to 2010 are classified as either economic or social indicators and present a roughly similar distribution, this entire time frame was partitioned in order to reflecting the specific themes and focus of each one of time intervals as well as capturing the number of KPIs proposed. When cross analyzing these time intervals with the triple bottom line classification of the KPIs, an evolution of the addressed dimensions can be shown (Table 2). The most prolific years both in terms of the number of proposed KPIs as well as the coverage of the different triple bottom line dimensions were from 2011 to 2015, accounting for 405 KPIs and representing $51.5 \%$ of the total number of KPIs. The 1900's and early 2000's, represented by the intervals 1993-1999 and 2000-2005, had a homogeneous distribution of KPIs, accounting for 140 each interval (17.8\% of the total), only in the economic and social dimensions. The selected studies that were published from 2006 to 2010 contributed with 102 indicators $(12.9 \%$ of the total) covering only economic and social topics. Table 2 provides the number of KPIs for each time interval, classified according to the triple bottom line dimension and Figure 4 provides an evolution outlook of the KPI dimensions over the years, in relative terms. 
Table 2 - Number of KPIs according to the triple bottom line dimensions for each time interval

\begin{tabular}{|c|c|c|c|c|c|}
\hline \multirow{2}{*}{$\begin{array}{c}\text { Triple Bottom Line } \\
\text { Dimensions }\end{array}$} & \multicolumn{5}{|c|}{ Number of KPIs } \\
\hline & 1993 to 1999 & 2000 to 2005 & 2006 to 2010 & 2011 to 2015 & Total \\
\hline Economic & 127 & 129 & 87 & 241 & 584 \\
\hline Social & 13 & 11 & 15 & 112 & 151 \\
\hline Environmental & \multirow{5}{*}{-} & \multirow{5}{*}{-} & \multirow{5}{*}{-} & 25 & 25 \\
\hline All dimensions & & & & 16 & 16 \\
\hline Economic and Social & & & & 7 & 7 \\
\hline $\begin{array}{c}\text { Social and } \\
\text { Environmental }\end{array}$ & & & & 2 & 2 \\
\hline $\begin{array}{l}\text { Economic and } \\
\text { Environmental }\end{array}$ & & & & 2 & 2 \\
\hline Total & 140 & 140 & 102 & 405 & 787 \\
\hline
\end{tabular}

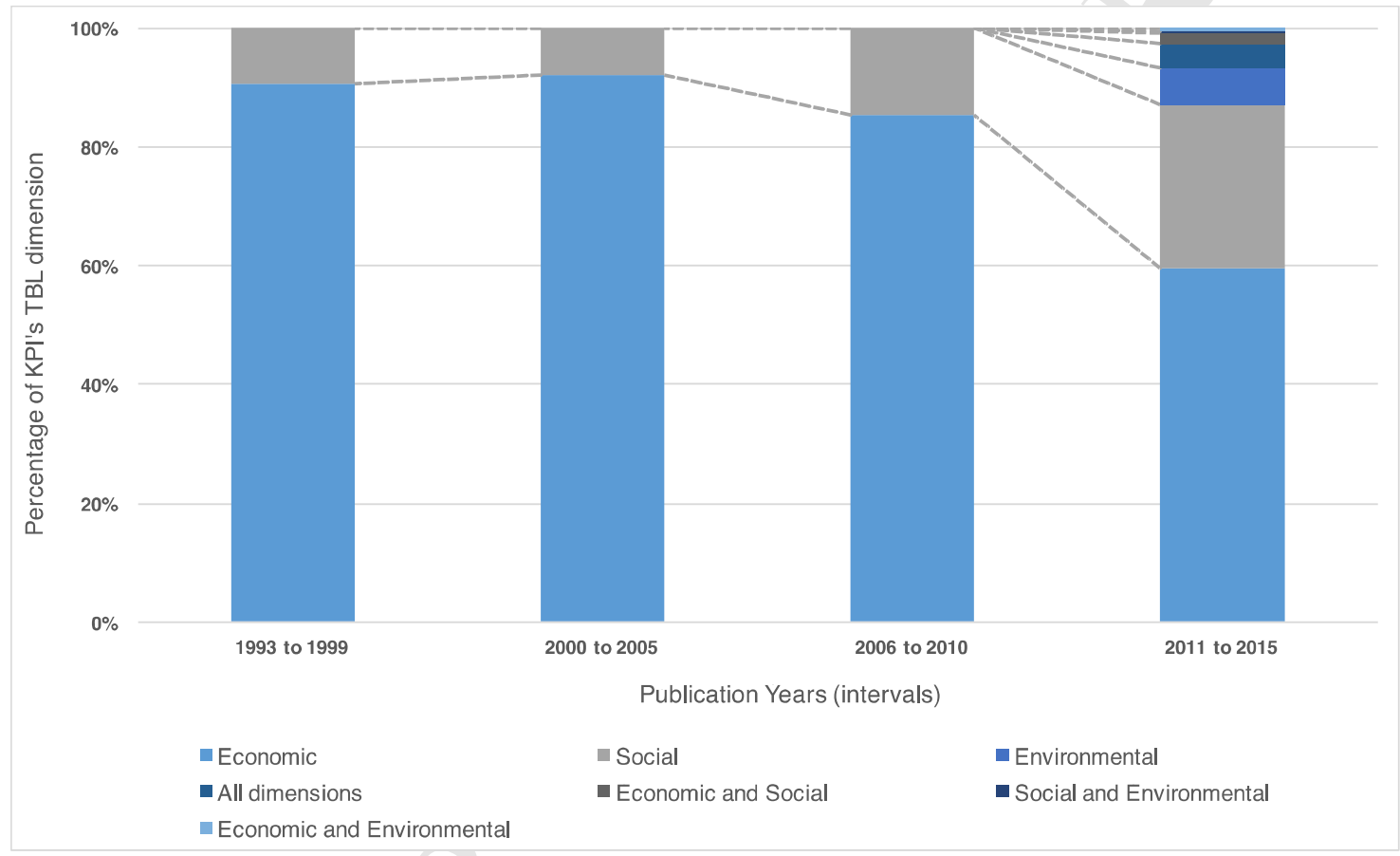

Figure 4 - Evolution of KPI's triple bottom line dimension over the years

\section{Discussion}

In the first selected papers, published along the 1990's, there are works dealing with management of product development projects and programs mainly focused on technical performance measures of the process and market adaptation and success. The main areas of these first studies covered: concurrent engineering programs (Goldense, 1993), success/failure of product development processes (Griffin and Page, 1993), development cycle times (Griffin, 1993), rapid product development (Goldense, 1994), R\&D effectiveness index as a standalone metric (McGrath and Romen, 1994), financial success metrics from a project perspective (Griffin and Page, 1996) and a first incorporation of an approach based on the Balanced Scorecard (Kaplan and Norton, 1992 ) with the four perspectives: customer, internal business, innovation \& learning and financial (Drongelen and Bilderbeek, 1999). The first proposed KPIs are mainly focused on: (i) market acceptance (Griffin and Page, 1996, 1993), (ii) traditional financial performance (Griffin and Page, 1996, 1993), (iii) technical efficiency (Goldense, 1994) and (iv) isolated indicators reflecting the innovation and learning perspective of an organization, such as 'number of ideas/findings', 'network building' or 'creativity/innovation level', proposed by (Drongelen and Bilderbeek, 1999).

The entire first decade of the 2000's followed a similar trend, as no environmental indicators had been proposed that far, with focus areas positioned at: (i) technology development (Ganguly et al., 2010), (ii) R\&D capability and characteristics (Choi and Ko, 2010; García-Valderrama and Mulero-Mendigorri, 2005), (iii) technical aspects based on indicators that were customized and proposed for large manufacturing companies (Vanek et 
al., 2008), (iv) other general technical aspects (Acosta et al., 2002; Buchheim, 2000; Shah et al., 2000), (v) BSC-based indicators for product development (Bai et al., 2007), (vi) adaptation indicators based on case studies (Buganza and Verganti, 2006), (vii) supplier indices (Humphreys et al., 2007) and (viii) generic indicators, covering different economical aspects of the product development process (Driva et al., 2001, 2000; Haque and Moore, 2004; Hauser, 2001).

The first proposed KPIs covered different layers of the organization, from product-level measures to companywide indicators. The emergence and consolidation of the Balanced Scorecard (Kaplan and Norton, 1992) as a predominant performance measurement system within companies could be defined as one of the main influencers on how the KPIs were initially classified and proposed by the literature. Furthermore, the social aspects reported in this particular period were completely focused on internal aspects of the organization and its employees' satisfaction, skills and training, touching upon theme such as esteem, behavior in-group, staffing ratio, team member's turnover and team satisfaction. Specifically, two metrics were tailored to capture and calculate team cohesiveness (member-time metric) and team communication (weighted-meeting time) (Ganapathy and Goh, 1997, 1996).

The environmental dimension and the multi-dimensional indicators come into play in the latter publications, resulting in a slightly more harmonized distribution in triple bottom line dimensions to the previously proposed KPIs. The 25 pure environmental indicators are proposed by (Garbie, 2014), (Ussui and Borsato, 2013) and (Nappi and Rozenfeld, 2015, 2013), mainly covering the topics of environmental standards and legislation, dissemination of environmental information across the value chain, environmental budget and certification, as well as levels of application of environmental-related practices, approaches and strategies, such as ecolabelling, ecodesign and remanufacturing. Therefore, it should be noted that the availability of process-oriented environmental indicators is much scarcer when compared to the available product-oriented environmental indicators, which populates the literature of ecodesign implementation, as shown by the comprehensive KPI database and selection guidelines proposed by (Issa et al., 2015).

This low occurrence of environmental indicators (3.2\%) might be attributed to the intrinsic intangible, uncertain and organizationally complex nature of product development processes and projects (Tatikonda and Rosenthal, 2000; Tatikonda, 2007). These characteristics pose significant challenges in defining specific environmental aspects and targets for processes to follow or be measured on. The main challenge is related to understanding how product development can be strategically assessed and monitored from an environmental standpoint (e.g. standards, legislations, dissemination of environmental information across value chain etc.) into the decision-making along the product development process. Within this context, the materialization of tailormade indicators for representing the environmental strategic and tactical practices (e.g. the ecodesign management practices proposed by Pigosso et al. (2013) or the cross-field propositions suggested by Johansson and Sundin (2014) are needed, since the majority of environmental indicators are directly related to the products. Since product development relies to a certain degree on intellectual activities and information flows and transactions, rather than on physical and chemical ones, the definition of environmental impacts and how product development processes are actually contributing to this dimension of triple bottom line might not be clearly and directly understood. In order to achieve such understanding, the product development must be critically evaluated in order to identify what kind of process-oriented environmental information is relevant for the company to keep track of in order to improve its environmental bottom line.

The alignment and combination of economic and environmental aspects in order to reach a superior sustainability performance has been studied in the literature and systematically reviewed by Johansson and Sundin (2014). The authors explore the complementarity between Lean and Green Product Development approaches and conclude that they share common grounds and are able to reach synergistic relationships. In regards to performance measurement, on one hand the lean indicators are essentially focused on effectiveness and efficiency of the product development processes, resembling many of the best practices advocated on the core of the product development literature. On the other hand, green indicators are substantially concerned with environmental performance, notably greenhouse gas metric (Johansson and Sundin, 2014). These claims are in line with the results of the present systematic literature review as it presents: (i) a fairly large coverage of economic indicators that could support lean approaches (e.g. process efficiency and effectiveness) and (ii) a clear scarcity on process-oriented environmental indicators, since that specific literature has been populated and dominated by product-specific measures. This fact can fine-tune and enhance the potential of future developments on the combination of both approaches and on how to best translate them into aligned performance indicators, in ways to stimulate the creation and deployment of specific indicators from a processoriented perspective.

Furthermore, the 10 proposed bi-dimensional KPIs, such as 'number of employees with incentives linked to environmental goals' (social and environmental) or 'number of pages in annual report devoted to new product development' (economic and social) are exclusively reported by (Nappi and Rozenfeld, 2015, 2013), whereas 
the 16 indicators touching all triple bottom line dimensions, such as 'percentage of resources/investments in sustainability' or 'number of sustainability aspects (social, environmental and economic) the selected concepts have the potential to improve' is exclusively proposed by (Chang and Tsai, 2015), (Ussui and Borsato, 2013) and (Nappi and Rozenfeld, 2015, 2013).

Additionally, the social indicators proposed in the latter publication go beyond the company's boundaries and embrace an external view on communities' affairs, accompanied by the preservation and fulfillment of human's needs and interests, such as the indicators dealing with child labor, social security, discrimination, freedom of association, involvement in the local community, health services, societal investment, fair trading, compliance with ethical guidelines, corruption and access to essential services (Garbie, 2014; Nappi and Rozenfeld, 2015, 2013). The internal aspects of employee's satisfaction and working conditions are also treated from a more broader perspective by: (i) encompassing elements of formal education, abilities and skills development, as well as accessibility to sources of knowledge, information and networking (Kim and Kim, 2015; Kulatunga et al., 2011; Nappi and Rozenfeld, 2015, 2013), (iii) team assessments from a risk perspective (Yim et al., 2015a, 2015b) and (iv) high-level management commitment, competencies, skills and involvement (Choi and Ko, 2010; Yim et al., 2015b).

There is an evident and relevant asymmetry between the number of KPIs proposed for each one of the triple bottom line dimensions and their combination in bi-dimensional and tri-dimensional indicators. Environmental and social aspects are partially reflected in economic transactions, even though those elements have been an increasingly part of business (Figge et al., 2002). This asymmetry is also supported by the appearance of only 2 sustainability-related journals in the results of the literature review, in the works of (Luz et al., 2015), (Jabbour et al., 2015) and (Chang and Tsai, 2015), accompanied by a lack of conferences focusing on sustainability. A challenge that is directly related to this heterogeneous distribution of KPIs is rendered to the high number of new aspects that the concept of sustainable development has brought for organizations to be accountable for, including issues outside their direct control and management, in which they have to apply value judgments, rather than hard data, to characterize (Keeble et al., 2003).

The large amount of proposed economic indicators supports the hypothesis that the performance of product development processes is still mainly captured and measured in companies in terms of their technical efficiency and financial metrics, based on hard data. This is also reflected in the high number of proposed KPIs that uniquely falls within the phases of Product Strategic Planning and Product Accompanying and Monitoring. These indicators are mainly devoted to understanding the real financial return of R\&D activities, their efficiency, and how the product success in the market can be replicated and maintained. Whenever considered in these stages, the social indicators are either referring to very specific organizational aspects or trying to capture customer satisfaction. Therefore, there is an evident gap of proactive and external-oriented social indicators for product development, whose main role would be to translate societal needs and issues more comprehensively into business opportunities and value, rather than solely measuring customer satisfaction.

Despite the reasonably high number of catalogued process-related KPIs in this research, the performance of product development, as a whole, is dominated by a product-oriented perspective, with indicators largely focusing on physical properties and attributes of specific products - this is also backed by the high amount of excluded studies $(96.2 \%)$ during the systematic review procedure. However, this clear distinction between process-related and product-related indicator is not always crystal-clear and might become the object of discussion and dispute. Furthermore, it should be noted that there is a symptomatic absence of support for defining, adapting and actually applying or using the proposed indicators, since the majority of the indicators are not proposed along with units of measurement, general instructions or formulas for their application.

When compared with previously executed researches in the area of performance measurement for product development processes, the novelty of this particular research can be highlighted. The work of (Costa et al., 2014) focuses on lean metrics for Research and Development, whereas the works of (Nappi and Rozenfeld, 2015, 2013; Nappi, 2014) are devoted to a broader view of performance measurement systems from a Product Lifecycle Management perspective. Finally the more specific ecodesign-related review is performed by Issa et al. (2015), with a clear focus on reviewing product-related environmental performance indicators and propose a selection guide for companies. Therefore, this research is mainly differentiated by: (i) its focus on processoriented indicators; (ii) the emphasis on product development based on a process reference model (Amaral and Rozenfeld, 2007; Rozenfeld, 2007); (iii) the consideration of an approach based on the triple bottom line, and (iv) the inclusion and treatment of business-related aspects in different organizational levels (strategic, tactical and operational) with a view to measuring performance in order to ultimately develop a business case for ecodesign implementation. 


\section{Final Remarks}

This paper reported the definition and systematization of a set of process-related KPIs for measuring sustainability performance of ecodesign integration into product development. The research methodology was designed on the grounds of a systematic literature review to cover performance measurement for product development from a process perspective as broadly as possible, accompanied by a critical analysis of the findings. The resulting 787 KPIs were catalogued and systematized in an online database for ready access and consultation. Even though this database was not intended to offer specific support for selecting and defining the performance indicators, it may constitute an additional resource for both academics and practitioners working with ecodesign implementation and the measurement of product development performance.

The main general findings of this research are: (i) product development performance, in general, has been widely discussed in the literature in terms of product characteristics, technical efficiency and financial returns; (ii) ecodesign performance is also constrained into product-related indicators and the pure environmental performance; (iii) there is neither consensus nor clear definitions on process vs. product indicators for product development, which leads to a somewhat fuzzy distinction and understanding of theses types of indicators; (iv) the assortment of topics covered by the systematized KPIs in the database is very broad, ranging from very specific document use indicators to very high-level corporate strategy indicators; (v) environmental performance is currently outside of focus in terms of process-related indicators, since product development processes are usually taken as intangible and uncertain;

Some limitations of this research can also be pointed out. Firstly, the KPI database was constructed based on purely academic sources, without considering potential systematic review of "state-of-the-practice" sources and databases. Secondly, the classification and systematization of the catalogued KPIs are subjected to the researchers' own judgments regarding the designated product development phases, triple bottom line dimensions and units of measurement to be assigned to each indicator. Finally, due to the abovementioned systemic lack of support for defining and using the indicators, their interpretation was sometimes solely based on their names and further definitions were made on a subjective fashion. The aforementioned limitations can be addressed by: (i) widening the scope of the literature review to cover corporate and practitioner-oriented sources to include highlights and insights from practice, which could potentially lead to a higher number of indicators and (ii) subject the KPIs definition and systematization to a panel of experts in the fields of product development, ecodesign and performance measurement.

In order to effectively capture and measure the potential business benefits of ecodesign implementation, more focus should be posed on process-oriented and sustainability-based indicators, covering aspects and dimensions beyond the ecodesign effects on product environmental performance. Therefore, future research should be pointed as a way to overcome potential limitations of this research, as well as propose actions to be taken within the overall research context this paper is positioned. The next step within the frame of this research is to crossanalyze and relate the KPIs in the database with ecodesign management practices at the strategic and tactical levels, highlighting the main gaps and needs for further KPI development, definition or tailoring.

Finally, this paper is part of a broader research effort aimed at developing a concrete business case for ecodesign implementation into product development processes. Therefore, besides the highlighted future development, suitable quantitative modeling techniques and methods will be selected and applied to the development of a prescriptive support tool for simulating the potential business benefits gained by implementing ecodesign. Additionally, this potential benefits might also be enhanced by other complementary approaches, such as PSS or practices for stimulating Social Innovation. These approaches have been increasingly studied and research points to important sustainability benefits derived directly from the conceptualization and implementation of new business models (e.g. offering a combination of products and services etc.) and tackling fundamental and challenging social issues (e.g. creating business value that is simultaneously shared with underprivileged communities and regions etc.). This prescriptive support tool should be instantiated with empirical data and geared towards laying out the fundamental rationale of how ecodesign can actually improve an organization's sustainability performance.

\section{Acknowledgments}

We express our sincere appreciation to CNPq (National Council for Scientific and Technological Development) in Brazil for their financial support (Grant Number 200869/2014-0), to the Technical University of Denmark for their institutional support and to the STOSIP (Strategic, Tactical and Operational Implementation of Sustainability into the Innovation Process) project, based on collaborative research between Swedish and Danish institutions. 


\section{References}

Acosta, C.L.., Araújo, C.S., Trabassos, L.., 2002. A review of product development performance metrics investigations with emphasis on the designer level, in: International Design Conference - Design 2002. pp. $1-6$.

Adriaanse, L.S., Rensleigh, C., 2013. Web of Science, Scopus and Google Scholar: A content comprehensiveness comparison. Electron. Libr. 31, 727-744. doi:10.1108/EL-12-2011-0174

Amaral, D.C., Rozenfeld, H., 2007. Integrating new product development process references with maturity and change management models, in: International Conference on Engineering Design - ICED 2007.

Ambec, S., Lanoie, P., 2008. Does It Pay to Be Green? A Systematic Overview. Acad. Manag. Perspect. 22, 4562. doi:10.5465/AMP.2008.35590353

Azapagic, A., 2003. Systems approach to corporate sustainability: a general management framework. Process Saf. Environ. Prot. 81, 303-316. doi:http://dx.doi.org/10.1205/095758203770224342

Bai, Z., Zhang, P., Liu, F., Tan, R., 2007. Product development performance measures in manufacturing firm, in: 2007 IEEE International Conference on Industrial Engineering and Engineering Management. pp. 926-929. doi:10.1109/IEEM.2007.4419327

Baumgartner, R.J., Ebner, D., 2010. Corporate sustainability strategies: Sustainability profiles and maturity levels. Sustain. Dev. 18, 76-89. doi:10.1002/sd.447

Bevilacqua, M., Ciarapica, F.E., Giacchetta, G., 2007. Development of a sustainable product lifecycle in manufacturing firms: a case study. Int. J. Prod. Res. 45, 4073-4098. doi:10.1080/00207540701439941

Bhander, G.S., Hauschild, M., Mcaloone, T., 2003. Implementing Life Cycle Assessment in Product Development 22, 255-267.

Biolchini, J., Mian, P.G., Candida, A., Natali, C., 2005. Systematic Review in Software Engineering. Rio de Janeiro. doi:10.1007/978-3-540-70621-2

Boks, C., 2006. The soft side of ecodesign. J. Clean. Prod. 14, 1346-1356. doi:10.1016/j.jclepro.2005.11.015

Boks, C., Stevels, a., 2007. Essential perspectives for design for environment. Experiences from the electronics industry. Int. J. Prod. Res. 45, 4021-4039. doi:10.1080/00207540701439909

Bourne, M., Neely, A., Platts, K., Mills, J., 2002. The success and failure of performance measurement initiatives: perceptions of participating managers. Int. J. Oper. Prod. Manag. 22, 1288-1310. doi:10.1108/01443570210450329

Buchheim, R.K., 2000. Developing performance metrics for a design engineering department. IEEE Trans. Eng. Manag. 47, 309-320. doi:10.1109/17.865900

Buganza, T., Verganti, R., 2006. Life-cycle flexibility: How to measure and improve the innovative capability in turbulent environments. J. Prod. Innov. Manag. 23, 393-407. doi:10.1111/j.1540-5885.2006.00212.x

Carroll, A.B., Shabana, K.M., 2010. The Business Case for Corporate Social Responsibility: A Review of Concepts, Research and Practice. Int. J. Manag. Rev. 12, 85-105. doi:10.1111/j.1468-2370.2009.00275.x

Chang, A.S., Tsai, C.Y., 2015. Sustainable design indicators: Roadway project as an example. Ecol. Indic. 53, 137-143. doi:10.1016/j.ecolind.2015.01.036

Choi, G.C.G., Ko, S.-S.K.S.-S., 2010. An integrated metric for R\&D innovation measurement. Technol. Manag. Glob. Econ. Growth (PICMET), 2010 Proc. PICMET' 10.

Costa, J.M.H., Oehmen, J., Rebentisch, E., Nightingale, D., 2014. Toward a better comprehension of Lean metrics for research and product development management. R\&D Manag. doi:10.1111/radm.12074

Delai, I., Takahashi, S., 2011. Sustainability measurement system: a reference model proposal. Soc. Responsib. J. 7, 438-471. doi:10.1108/17471111111154563

Driva, H., Pawar, K.S., Menon, U., 2001. Performance evaluation of new product development from a company perspective. Integr. Manuf. Syst. 12, 368-378. doi:10.1108/EUM0000000005714

Driva, H., Pawar, K.S., Menon, U., 2000. Measuring product development performance in manufacturing organisations. Int. J. Prod. Econ. 63, 147-159. doi:10.1016/S0925-5273(99)00007-9

Drongelen, I.C.K., Bilderbeek, J., 1999. R\&D performance measurement: More than choosing a set of metrics. 
R\&D Manag. 29, 35. doi:10.1111/1467-9310.00115

Durkacova, M., Lavin, K., Karjust, K., 2012. KPI Optimization for Product Development Process, in: Annals of DAAAM for 2012 \& Proceedings of the 23rd International DAAAM Symposium. pp. 1079-1084.

EDC, 2014. Costs and Benefits of Ecodesign: Measurement, Valuation and Related Policy Issues.

Elkington, J., 1997. Cannibals with Forks: The Triple Bottom Line of the 21st Century Business. New Society Publishers, Oxford.

Figge, F., Hahn, T., Schaltegger, S., Wagner, M., 2002. The sustainability balanced scorecard - Linking sustainability management to business strategy. Bus. Strateg. Environ. 11, 269-284. doi:10.1002/bse.339

Fiksel, J., McDaniel, J., Spitzley, D., 1998. Measuring Product Sustainability. J. Sustain. Prod. Des.

Ganapathy, B.K., Goh, C.., 1997. A Hierarchical System of Performance Measures for Concurrent Engineering. Concurr. Eng. Res. Appl. 5, 137-143.

Ganapathy, B.K., Goh, C.., 1996. Process-based performance measures for concurrent engineering, in: Proceedings of the 1996 27th Annual Meeting of the Decision Sciences Institute. pp. 1210-1212.

Ganguly, A., Nilchiani, R., Farr, J. V., 2010. Defining a Set of Metrics to Evaluate the Potential Disruptiveness of a Technology. Eng. Manag. J. 22, 34-44. doi:10.1080/10429247.2010.11431851

Garbie, I.H., 2014. An analytical technique to model and assess sustainable development index in manufacturing enterprises. Int. J. Prod. Res. 52, 4876-4915. doi:10.1080/00207543.2014.893066

García-Valderrama, T., Mulero-Mendigorri, E., 2005. Content validation of a measure of R\&D effectiveness. R\&D Manag. 35, 311-331. doi:10.1111/j.1467-9310.2005.00392.x

Gauthier, C., 2005. Measuring corporate social and environmental performance: The extended life-cycle assessment. J. Bus. Ethics 59, 199-206. doi:10.1007/s10551-005-3416-x

Gavel, Y., Iselid, L., 2008. Web of Science and Scopus: a journal title overlap study. Online Inf. Rev. 32, 8-21. doi: $10.1108 / 14684520810865958$

Gaziulusoy, a. I., Boyle, C., McDowall, R., 2013. System innovation for sustainability: A systemic double-flow scenario method for companies. J. Clean. Prod. 45, 104-116. doi:10.1016/j.jclepro.2012.05.013

Goldense, B.., 1994. Rapid Product Development Metrics. World Cl. Des. to Manuf. 1, 21-28. doi:10.1108/09642369210049924

Goldense, B.., 1993. Metrics That Drive CE Program Development, in: Autofact '93. Society of Manufacturing Engineers, Chicago.

GRI, 2014. G4 Sustainability Reporting Guidelines 97.

Griffin, A., 1993. Metrics for measuring product development cycle time. J. Prod. Innov. Manag. 10, 112-125. doi:10.1016/0737-6782(93)90003-9

Griffin, A., Page, A.L., 1996. PDMA Success Measurement Project: Recommended Measures for Product Development Success and Failure. J. Prod. Innov. Manag.

Griffin, A., Page, A.L., 1993. An interim report on measuring product development success and failure. J. Prod. Innov. Manag. 10, 291-308. doi:10.1016/0737-6782(93)90072-X

Hallstedt, S.I., Thompson, A.W., Lindahl, P., 2013. Key elements for implementing a strategic sustainability perspective in the product innovation process. J. Clean. Prod. 51, 277-288. doi:10.1016/j.jclepro.2013.01.043

Handfield, R.B., Melnyk, S. a., Calantone, R.J., Curkovic, S., 2001. Integrating environmental concerns into the design process: The gap between theory and practice. IEEE Trans. Eng. Manag. 48, 189-208. doi:10.1109/17.922478

Haned, N., Lanoie, P., Plouffe, S., Vernier, M.-F., 2015. Profitability of Ecodesign: an Economic Analysis 133.

Haque, B., Moore, M.J., 2004. Measures of performance for lean product introduction in the aerospace industry. Proc. Inst. Mech. Eng. -- Part B -- Eng. Manuf. 218, 1387-1398. doi:10.1243/0954405042323496

Hauser, J.R., 2001. Metrics thermostat. J. Prod. Innov. Manag. doi:10.1111/1540-5885.1830134 
Humphreys, P., Huang, G., Cadden, T., McIvor, R., 2007. Integrating design metrics within the early supplier selection process. J. Purch. Supply Manag. 13, 42-52. doi:10.1016/j.pursup.2007.03.006

Hutchins, M.J., Sutherland, J.W., 2008. An exploration of measures of social sustainability and their application to supply chain decisions. J. Clean. Prod. 16, 1688-1698. doi:10.1016/j.jclepro.2008.06.001

Hynds, E.J., Brandt, V., Burek, S., Jager, W., Knox, P., Parker, J.P., Schwartz, L., Taylor, J., Zietlow, M., 2014. A Maturity Model for Sustainability in New Product Development. Res. Technol. Manag. 57, 50-57. doi: $10.5437 / 08956308 \times 5701143$

ISO, 2011. ISO 14.006 - Environmental management systems: guidelines for incorporating ecodesign.

ISO, 2002. ISO 14.062 - Environmental Management: integrating environmental aspects into product design and development.

Issa, I.I., Pigosso, D.C.A., McAloone, T.C., Rozenfeld, H., 2015. Leading product-related environmental performance indicators: a selection guide and database. J. Clean. Prod. doi:10.1016/j.jclepro.2015.06.088

Jabbour, C.J.C., Jugend, D., Jabbour, A.B.L.S., Gunasekaran, A., Latan, H., 2015. Green product development and performance of Brazilian firms : measuring the role of human and technical aspects. J. Clean. Prod. 87, 442-451. doi:10.1016/j.jclepro.2014.09.036

Johansson, G., Sundin, E., 2014. Lean and green product development: Two sides of the same coin? J. Clean. Prod. 85, 104-121. doi:10.1016/j.jclepro.2014.04.005

Kaplan, R.S., Norton, D.P., 1992. The Balanced Scorecard - Measures that Drive Performance. Harv. Bus. Rev. 70, 71-79.

Keeble, J.J., Topiol, S., Berkeley, S., 2003. Using indicators to measure sustainability performance at a corporate and project level. J. Bus. Ethics 44, 149-158. doi:10.1023/A:1023343614973

Keong Choong, K., 2013. Understanding the features of performance measurement system: a literature review. Meas. Bus. Excell. 17, 102-121. doi:10.1108/MBE-05-2012-0031

Kim, H.-B., Kim, Y.-S., 2015. Performance indices for quantitative measurement of R\&amp;D results in private construction companies. KSCE J. Civ. Eng. 19, 814-830. doi:10.1007/s12205-015-2369-6

Kulatunga, U., Amaratunga, D., Haigh, R., 2011. Structured approach to measure performance in construction research and development. Int. J. Product. Perform. Manag. 60, 289-310. doi:10.1108/17410401111112005

Labuschagne, C., Brent, A.C., van Erck, R.P.G., 2005. Assessing the sustainability performances of industries. J. Clean. Prod. 13, 373-385. doi:10.1016/j.jclepro.2003.10.007

Luz, L.M., de Francisco, A.C., Piekarski, C.M., 2015. Proposed model for assessing the contribution of the indicators obtained from the analysis of life-cycle inventory to the generation of industry innovation. J. Clean. Prod. 96, 339-348. doi:10.1016/j.jclepro.2014.03.004

Mathieux, F., Rebitzer, G., Ferrendier, S., Simon, M., mFroelich, D., 2001. Ecodesign in the European Electr(on)ics Industry - An analysis of the current practices based on cases studies - An analysis of the current practices based on cases studies. J. Sustain. Prod. Des. 1, 233-245. doi:10.1023/A:1024670630297

McAloone, T., Bey, N., 2009. Environmental improvement through product development: A guide.

Mccool, S.F., Stankey, G.H., 2004. Indicators of Sustainability: Challenges and Opportunities at the Interface of Science and Policy. Environ. Manage. 33, 294-305. doi:10.1007/s00267-003-0084-4

McGrath, M.E., Romen, M.N., 1994. The R\&D Effectiveness Index: A Metric for Product Development Performance. J. Prod. Innov. Manag. 11, 213. doi:10.1108/09642369210063063

Meadows, D., 1998. Indicators and information systems for sustainable development. A Rep. to Balat. Gr. 1-25.

Nappi, V., 2014. Framework para Desenvolver um Sistema de Medição de Desempenho para PLM ( Product Lifecycle Management ) com Indicadores de Sustentabilidade. Universidade de São Paulo.

Nappi, V., Rozenfeld, H., 2015. The Incorporation of Sustainability Indicators into a Performance Measurement System. Procedia CIRP 26, 7-12. doi:10.1016/j.procir.2014.07.114

Nappi, V., Rozenfeld, H., 2013. Sustainability Performance Indicators for Product Lifecycle Management, in: Proceedings of the 22th International Confgress of Mechanical Engineering (COBEM). ABCM, Ribeirão Preto, pp. 4071-4082. 
Neely, A., Adams, C., Kennerly, M., 2002. The performance prism : The scorecard for measuring and managing business success. Prentice Hall.

Neely, A., Gregory, M., Platts, K., 2005. Performance measurement system design: A literature review and research agenda, International Journal of Operations \& Production Management. doi: $10.1108 / 01443570510633639$

Nielsen, P.., Wenzel, H., 2002. Integration of environmental aspects in product development: a stepwise procedure based on quantitative life cycle assessment. J. Clean. Prod. 10, 247-257. doi:10.1016/S09596526(01)00038-5

Oman, S.K., Tumer, I.Y., Wood, K., Seepersad, C., 2013. A comparison of creativity and innovation metrics and sample validation through in-class design projects. Res. Eng. Des. 24, 65-92. doi:10.1007/s00163012-0138-9

Pascual, O., Stevels, A., 2004. Ecodesign in industry is not an environmental issue, in: Proceedings of Electronic Goes Green. Berlin, pp. 855-859.

Pigosso, D., Rozenfeld, H., 2012. Ecodesign Maturity Model: the Ecodesign Practices, in: Matsumoto, M., Umeda, Y., Massui, K., Fukushige, S. (Eds.), Design for Innovative Value Towards a Sustainable Society - Proceedings of EcoDesign 2011: 7th International Symposium on Environmentally Conscious Design and Inverse Manufacturing. SpringerLink, pp. 424-429.

Pigosso, D.C. a, Rozenfeld, H., McAloone, T.C., 2013. Ecodesign maturity model: A management framework to support ecodesign implementation into manufacturing companies. J. Clean. Prod. 59, 160-173. doi:10.1016/j.jclepro.2013.06.040

Pigosso, D.C.., McAloone, T.C., Rozenfeld, H., 2015. Characterization of the State-of-the-art and Identification of Main Trends for Ecodesign Tools and Methods: Classifying Three Decades of Research and Implementation. J. Indian Inst. Sci. 95, 405-427.

Plouffe, S., Lanoie, P., Berneman, C., Vernier, M.F., 2011. Economic benefits tied to ecodesign. J. Clean. Prod. 19, 573-579. doi:10.1016/j.jclepro.2010.12.003

Rozenfeld, H., 2007. Reference model for managing product development, in: Seliger, G. (Ed.), Sustainability in Manufacturing: Recovery of Resources in Product and Material Cycles. Springer, pp. 193-206.

Seuring, S., Müller, M., 2008. From a literature review to a conceptual framework for sustainable supply chain management. J. Clean. Prod. 16, 1699-1710. doi:10.1016/j.jclepro.2008.04.020

Shah, J.J., Kulkarni, S. V., Vargas-Hernandez, N., 2000. Evaluation of Idea Generation Methods for Conceptual Design: Effectiveness Metrics and Design of Experiments. J. Mech. Des. 122, 377. doi:10.1115/1.1315592

Short, T., Lee-Mortimer, A., Luttropp, C., Johansson, G., 2012. Manufacturing, sustainability, ecodesign and risk: Lessons learned from a study of Swedish and English companies. J. Clean. Prod. 37, 342-352. doi:10.1016/j.jclepro.2012.07.037

Sikdar, S.K., 2003. Sustainable development and sustainability metrics. AIChE J. 49, 1928-1932. doi:10.1002/aic.690490802

Sundin, E., Nässlander, E., Lelah, A., 2015. Sustainability indicators for small and medium-sized enterprises (SMEs) in the transition to provide Product-Service Systems (PSS). Procedia CIRP 30, 149-154. doi:10.1016/j.procir.2015.02.155

Tatikonda, M. V., 2007. Product Development Performance Measurement. Handb. New Prod. Dev. 1-22.

Tatikonda, M. V., Rosenthal, S.R., 2000. Technology novelty, project complexity, and product development project execution success: A deeper look at task uncertainty in product innovation. IEEE Trans. Eng. Manag. 47, 74-87. doi:10.1109/17.820727

United Nations, 2007. Indicators of Sustainable Development : Guidelines and Methodologies. doi:10.1016/j.cirpj.2010.03.002

United Nations Global Compact, 2014. Guide to Corporate Sustainability.

Ussui, P.R.S., Borsato, M., 2013. Sustainability indicators for the product development process in the auto parts industry. 20th ISPE Int. Conf. Concurr. Eng. CE 2013 - Proc. 481-493. doi:10.3233/978-1-61499-302-5481 
Vallance, S., Perkins, H.C., Dixon, J.E., 2011. What is social sustainability? A clarification of concepts. Geoforum 42, 342-348. doi:10.1016/j.geoforum.2011.01.002

Van Hemel, C., Cramer, J., 2002. Barriers and stimuli for ecodesign in SMEs. J. Clean. Prod. 10, 439-453. doi:10.1016/S0959-6526(02)00013-6

Vanek, F., Jackson, P., Grzybowski, R., 2008. Model Based Systems Engineering with Department of Defense Architectural Framework. Syst. Eng. 14, 305-326. doi:10.1002/sys

Veleva, V., Ellenbecker, M., 2001. Indicators of sustainable production: framework and methodology. J. Clean. Prod. 9, 519-549. doi:10.1016/S0959-6526(01)00010-5

Veleva, V., Hart, M., Greiner, T., Crumbley, C., 2003. Indicators for measuring environmental sustainability: a case study of the pharmaceutical industry. Benchmarking An Int. J. 10, 107-119. doi:10.1108/14635770310469644

Willard, B., 2005. The NEXT Sustainability Wave: Building Boardroom Buy-In. New Society Publishers, Gabriola Island, BC, Canada.

Yim, R., Castaneda, J., Doolen, T., Tumer, I., Malak, R., 2015a. Managing risk in projects. Proj. Manag. J. 46, 63-75. doi:10.1002/pmj

Yim, R., Castaneda, J., Doolen, T., Tumer, I., Malak, R., 2015b. A study of the impact of project classification on project risk indicators. Int. J. Proj. Manag. 33, 863-876. doi:10.1016/j.ijproman.2014.10.005 


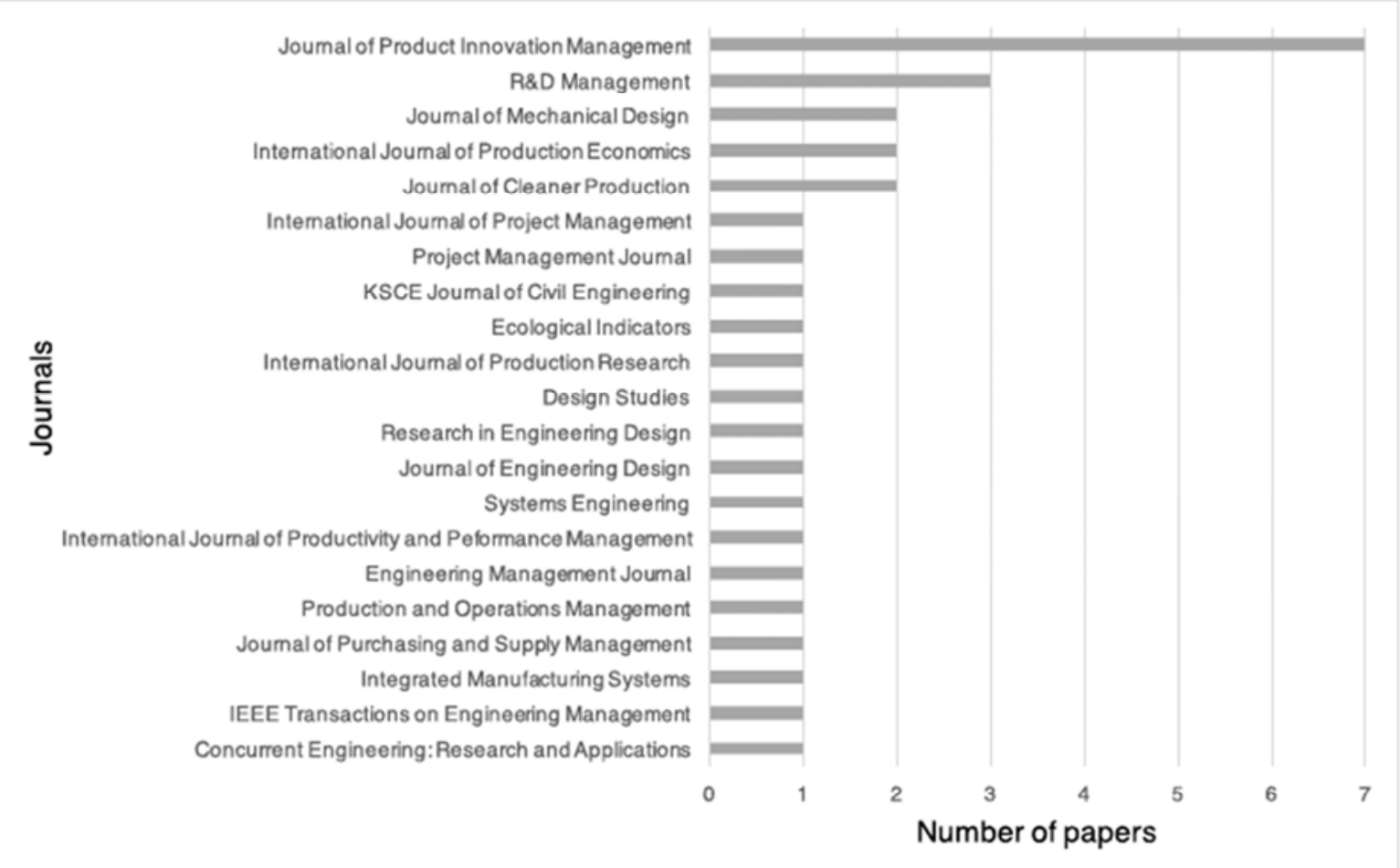




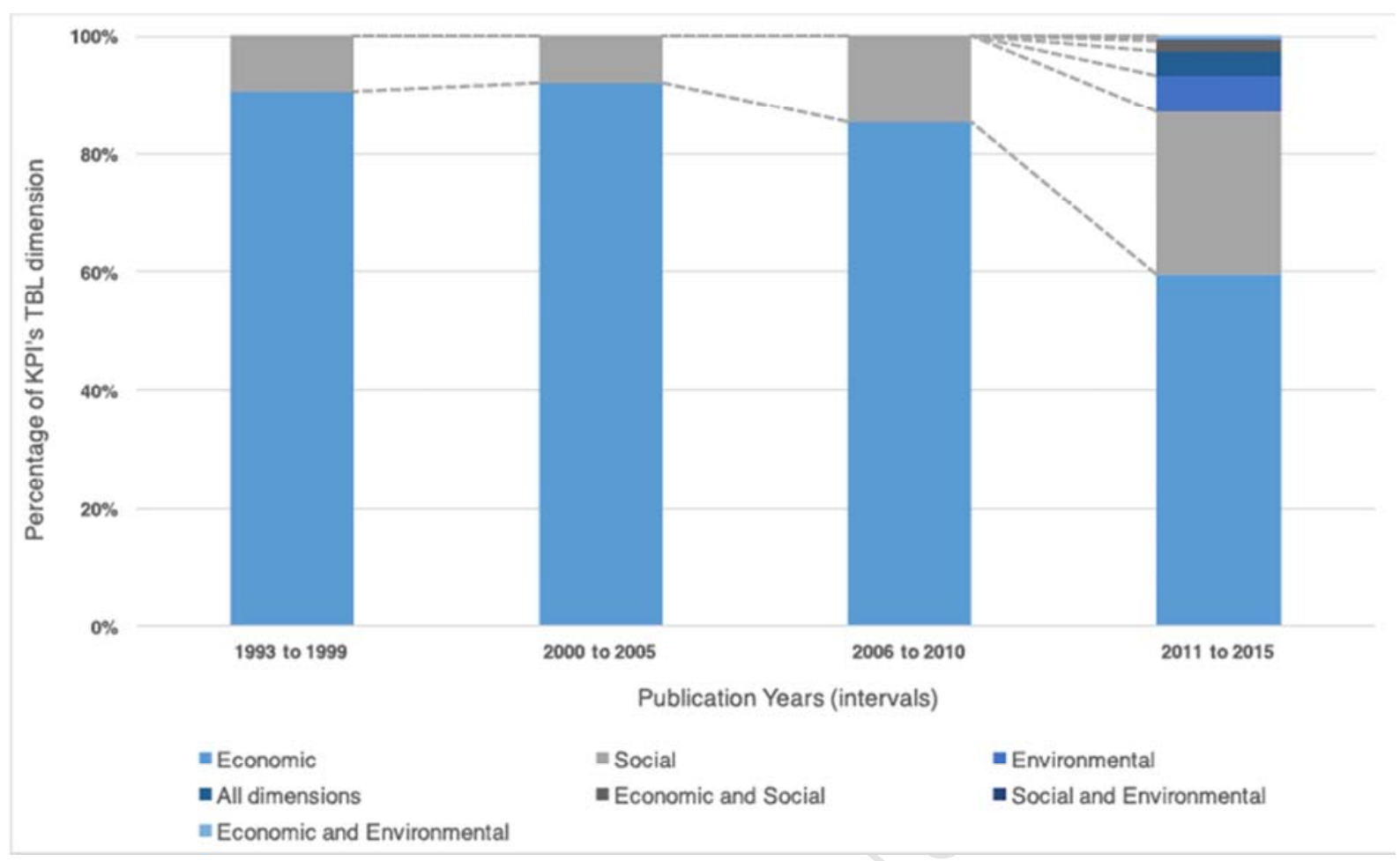

